\title{
UTICAJ RAZVOJA PREDUZETNIŠTVA I LIDERSTVA NA EKONOMSKI RAZVOJ
}

\author{
THE IMPACT OF ENTREPRENEURSHIP AND \\ LEADERSHIP DEVELOPMENT ON ECONOMIC \\ DEVELOPMENT
}

\section{Milosav Miličković}

Poslovni i pravni fakultet, „MB” Univerzitet, Beograd, Srbija

\section{Bilal Zahrah Miftah Alshafie}

Poslovni i pravni fakultet, „MB” Univerzitet, Beograd, Srbija

\section{Miroslav Jevremović}

Poslovni i pravni fakultet, „MB” Univerzitet, Beograd, Srbija

CMESTE

JEL kategorija rada: D13, L26

\begin{abstract}
Apstrakt
Razvoj preduzetništva i liderstva predstavlja oslonac razvoja svakog društva. U tržišnoj ekonomiji stanje preduzetništva se svakodnevno menja $i$ potrebno je pronalaziti nove metode njegovog razvoja $i$ prilagođavanja tržišnim prilikama. Srbija se danas nalazi u teškoj ekonomskoj situaciji. Globalna ekonomska kriza zaustavila je zakasneli tranzicioni oporavak zemlje u momentu kada je počeo da se hvata zalet. Put ka njenom ozdravljenju vodi kroz bolne mere: racionalizaciju predimenzioniranog javnog sektora $i$ ozbiljnu finansijsku disciplinu, kao i promovisanje preduzetništva $i$ liderstva kao strategije razvoja, bez kojih održivi privredni rast neće biti moguć. Cilj ovog rada jeste da doprinos opisu i analizi razvoja preduzetništva i liderstva, sa namerom da on doprinese ubrzanijem razvoju i u Srbiji. U radu su posebno analizirani pojam, opšte stanje i značaj preduzetništva, odnos preduzetništva i liderstva i uloga preduzetništva u ekonomskom razvoju. Na osnovu analize izvršene u radu, autori su zaključili da preduzetničke prilike proizlaze iz tržišnih promena, a da savremeno, brzo promenjljivo $i$ nesigurno poslovno okruženje predstavlja teoretski potencijalnu oblast za preduzetničke aktivnosti.
\end{abstract}

Ključne reči: ekonomski razvoj, preduzetništvo, inovacije, liderstvo

$\begin{array}{ll} & \text { Abstract } \\ \text { Adresa autora zaduženog za korespodenciju } & \begin{array}{l}\text { The development of entrepreneurship and } \\ \text { leadership is the backbone of the development of } \\ \text { Milosav Miličković } \\ \text { any society. In a market economy, the state of }\end{array} \\ 70 \text { milickovicm@amail.com } & \text { Publikovano: april } 2021\end{array}$


entrepreneurship changes every day and it is necessary to find new methods of its development and adaptation to market conditions. Today, Serbia is in a difficult economic situation. The global economic crisis halted the country's belated transitional recovery the moment the momentum began to take hold. The road to its recovery leads through painful measures: rationalization of the oversized public sector and serious financial discipline, as well as the promotion of entrepreneurship and leadership as development strategies, without which sustainable economic growth will not be possible. This paper aims to contribute to the description and analysis of the development of entrepreneurship and leadership, with the intention that it contributes to faster development in Serbia. The paper analyzes the concept, general state, and importance of entrepreneurship, the relationship between entrepreneurship and leadership, and the role of entrepreneurship in economic development. Based on the analysis performed in the paper, the authors concluded that entrepreneurial opportunities arise from market changes and that the modern, rapidly changing and uncertain business environment is a theoretically potential area for entrepreneurial activities.

Keywords: economic development, entrepreneurship, innovation, leadership

\section{PREDUZETNIŠTVO - OPŠTE STANJE I ZNAČAJ}

Prema Sumpeteru (1934), preduzetništvo je pokretačka snaga inovacija, i generalno pokretač ekonomskog razvoja. Vennekers i Thurik (1999) i Đardin (2011) u svojim istraživanjima pronalaze da osnivanje novih firmi može igrati ključnu ulogu $\mathrm{u}$ podsticanju konkurencije, izazivanje i podsticanje inovacija, pojavu novih sektora; $u$ tom kontekstu preduzetnici koji vode nove firme mogu nadoknaditi restrukturiranje zrelih sektora. Značaj preduzetništva naglašava se i po pitanju inovacija i prelivanju znanja. Audretsch i Keilback (2005) ukazuju da je preduzetništvo ključna pokretačka sila u procesu izbora inovacija, a time i stvaranju raznovrsnih znanja, koja zauzvrat, služe kao mehanizam olakšavanja prelivanja takvog znanja među pojedincima. (Baroš, 2007, str. 55) Praag i Versloot (2007) zaključuju da preduzetnici imaju veoma važnu i specifičnu ulogu u privredi. Oni stvaraju zaposlenost, doprinose rastu produktivnosti, proizvodnje i komercijalizaciji inovacija, i na taj način stvaraju pozitivne efekte prelivanja znanja na regionalnoj osnovi. (Bebera, Leković, \& Vasiljev, 2008)

Preduzetništvo je važno jer je ekonomski mehanizam kroz koji neefikasnosti u ekonomijama se identifikuju i ublažavaju. Prema OECD (1998) „preduzetništvo je centralni deo funkcionisanja tržišne ekonomije". Small Business Administration je otišao još dalje, pa kaže da je „ključni barometer ekonomskih sloboda i blagostanja u stvaranju novih i malih firmi u svim sektorima privrede po svim segmentima društva“. (Bobara, 2012, str. 31)
I dok se početkom 20-og veka, razvoj privredne aktivnosti zasnivao na velikim preduzećima i masovnoj proizvodnji koje je donelo blagostanje nacijama, mala preduzeća su bila osuđena na propast i tretirana su čak kao kočnica na putu razvoja. $U$ većini razvijenih ekonomija uspeh $u$ posleratnom periodu se zasnivao na velikom poduhvatu i smatralo se da su oni jedini sposobni da u skladu sa kodeksom industrijskog društva, razvijaju ekonomiju. Uspeh se zasnivao na šest suštinskih principa: standardizacija, specijalizacija, sinhronizacija, koncentracija, maksimizacija i centralizacija. Kasnije, krajem prošlog veka, javljaju se brojni dokazi da se ekonomska aktivnost udaljila od velikih firmi ka malim firmama. Schumacher (1973) tvrdi da će džinovske organizacije i rast specijalizacije dovesti do ekonomske neefikasnosti na makroekonomskom nivou i kao alternativu ponudio sistem posredničkih tehnologija zasnovanih na malim proizvodnim jedinicama. Tada se činilo da sistem velikih poduhvata nije doveo do ekonomskog uspeha kako se očekivalo. U 1980-im godinama, stagflacija i visoka stopa nezaposlenosti izazvala je veći interes ka identifikovanju faktora koji određuju ekonomski rast i razvoj. Kasnije, došlo je do pojačanog interesa za ocenjivanje uloge malih firmi i preduzetništva $\mathrm{i}$ njihove uloge $\mathrm{u}$ ekonomskom rastu. (Babović, 2012, str. 31) Poseban doprinos malih i srednjih preduzeća je uočen na tržištu rada, gde je viđeno da $80 \%$ svih novih radnih mesta su stvorila mala preduzeća u Sjedinjenim Američkim Državama (SAD). U SAD mala $i$ srednja preduzeća generišu više od polovine 
bruto društveni proizvod BDP i više od $50 \%$ svih izvoznih aktivnosti vrše preduzeća sa manje od 20 zaposlenih. Neke od najbrže rastućih ekonomija na svetu (npr, Tajvan, Hong Kong), su duboko ukorenjene u malim preduzećima. Više od $80 \%$ japanskih zaposlenih radi u malim i srednjim preduzećima, gde preduzeća zapošljavaju u proseku 9 zaposlenih, u poređenju sa 4 zaposlenih u EU. U Nemačkoj, preduzeća sa manje od 500 zaposlenih proizvode dve trećine BDP-a, i zapošljavaju 4 od 5 radnika. U poslednjih nekoliko godina, preduzetništvo predstavlja glavni izvor otvaranja novih radnih mesta $\mathrm{i}$ doprinosi ekonomskom rastu i nacionalnom prosperitetu. Kao posledica toga, učinjeni su značajni napori u pokušaju da se razume ovaj fenomen. (Karavidić, 2018)

$\mathrm{U}$ principu, postojanje malih preduzeća u bilo kojoj zemlji je od vitalne važnosti jer oni čine značajan doprinos u povećanju doprinosa ekonomske aktivnosti i otvaranju novih radnih mesta. (Karić, 1992, str. 69)

\section{DEFINISANJE PREDUZETNIŠTVA}

Termin „preduzetništvo“ koristi se u kontekstu poslovanja više od dva veka, međutim i pored toga, ono ostaje oblast u razvoju koja je osetljiva na varijacije $u$ značenju, te $s$ toga, ne postoji jedinstvena definicija pojma. To je $s$ toga, što je pojam preduzetništva evoluirao tokom vremena, ali je i dalje širok pojam koji obuhvata različita značenja ili funkcije u različitim kontekstima, na primer, u pojedinačnom kontekstu, u organizacionom kontekstu i kulturnom kontekstu. Zato je od velikog značaja da se istraže takvi konteksti.

Preduzetništvo se definiše kao proces koji stvara vrednost pravljenjem unikatnih kombinacija resursa koji stvaraju nove proizvode, usluge, procese, organizacione oblike, izvore snabdevanja i tržišnih mogućnosti. To je veoma inovativan proces i uključuje preuzimanje rizika i koordinaciju načina ponašanja u cilju funkcionisanja kao holističkog procesa. (Petković, 2009, str. 88)

Preduzetništvo je okarakterisano kao i intrigantno i zanimljivo, ali jednako neuhvatljiv ili nedefinisan koncept. Dakle, postoji mnogo definicija termina preduzetništvo kao što postoji i mnogo autora. Za razliku od drugih disciplina upravljanja, kao što je Ekonomija tamo gde je opšteprihvaćena definicija, pažljivo ispitivanje preduzetničke literature zaključuje da ne postoji jedinstvena definicija preduzetništva. Postojeće definicije su identifikovale preduzetništvo sa različitim funkcijama kao što su koordinacija proizvodnih resursa, uvođenje inovacija, preuzimanje rizika i ostali elementi vezani za kapital i bogastvo. Razlog za nemogućnost definisanja preduzetništva leži u interdisciplinarnosti koncepta i to: uključujući naučnike iz oblasti ekonomije, poslovne strategije, organizacionog ponašanja, sociologije i psihologije. U poslednjoj deceniji, međutim, preduzetništvo se izučava kao nezavisna oblast, sa multidisciplinarnim aspektom ali uglavnom povezanim sa školama menadžmenta. (Petrović, Cvijanović, \& Vukotić, 2014, str. 26)

Termin „preduzetnik“ uveo je još 1732 godine R Cantillon u svom delu Essai sur la Nature du Commerce en Général. U njegovom viđenju, centralna komponenta definicije preduzetnika gravitira oko preuzimanja rizika. Kasnije je J.B Say izjavio da preduzetnik pomera ekonomske resurse iz područja niže produktivnosti u oblasti više produktivnosti. Najobuhvatnija definicija preduzetništva vezuje se za ime J Schumpeter. Njegovo viđenje preduzetnika se zasniva, pre svega, na inovativnoj ulozi preduzetnika. Preduzetnici nisu samo inovatori i, $s$ toga, agenti promena, već i koordinatori proizvodnje. On je smatrao da se preduzetništvo javlja kroz pet uslova i to: nove robe, nove metode proizvodnje, nova tržišta, novi izvori materijala ili nove oranizacione forme. Prema šumpeterovskom mišljenju, preduzetnički proces predstavlja jedan od ključnih faktora u ekonomskom razvoju regiona/zemlje. Kirzner (1973) vidi preduzetnika kao nekog ko reaguje na tržišne mogućnosti, a ne da in stvara. Zatim, Gilder (1980) smatra da je preduzetnik supermen koji zna skrivene zakone ekonomije i koji doprinosi napretku. Takođe, on se bori protiv siromaštva stvaranjem novih radnih mesta. Novije definicije preduzetništva naglašavaju proces i na ljudskom faktoru zasnovane definicije preduzetništva. Tako, Shane, Venketeraman, (2000) vide preduzetništvo kao proces koji uključuje otkrivanje, evaluaciju i eksploataciju mogućnosti 
da uvede nove proizvode, usluge, procese, načine nastupa na novim tržištima. Preduzetništvo je s toga, kreativan ljudski proces, onaj koji mobiliše resurse sa jednog nivoa produktivnosti u drugi viši nivo. To podrazumeva volju pojedinca da preuzme odgovornost i mentalnu sposobnost obavljanja zadataka od ideje do realizacije. Druga komponenta preduzetništva sastoji se u identifikovanju mogućnosti gde drugi ljudi vide haos, protivrečnosti, ili zbunjenost. Adenutsi (2009) definiše preduzetništvo kao „identifikaciju poslovnih mogućnosti i mobilizaciju ekonomskih resursa za pokretanje novog biznisa ili revitalizacije postojećih u uslovima rizika i neizvesnosti, u cilju sticanja profita u privatnom vlasništvu“. Jednostavnije rečeno, preduzetništvo podrazumeva inovativne, profitno orijentisane ideje i realne napore koje čine kombinaciju oskudnih resursa i mogućnosti kroz privatne inicijative. On takođe navodi da u savremenom svetu globalizacije, „preduzetništvo i razvoj proizvodnih kapaciteta u privatnom sektoru postali su neophodni za uvođenje zemlje u globalne tokove trgovine i razvijanje mreža", i iako vlada utiče na stvaranje radnih mesta, ona u privatnom sektoru još uvek nedostaju. I zato vlade i donosioci odluka moraju da gledaju preduzetništvo u kombinaciji sa inovacijama $i$ održivim ekonomskim rastom, kao i u ispunjenju mnogih drugih društvenih izazova iz okruženja sa kojima se zemlja suočava. (Radovanović, 2006, str. 21)

\section{PREDUZETNIŠTVO I LIDERSTVO}

lako postoji prisutnost u mišljenjima različitosti između lidera i preduzetnika, objektivna stvarnost, multipliciranost aktivnosti i savremeno poslovanje ukazuju da između ovih aktivnosti dolazi sve više i dublje do konvergencije $i$ integracije, jer se gotovo imperativno nameće potreba da dobri lideri budu sposobni preduzetnici. To proizilazi iz osobina lidera kao što su: inicijativnost, inventivnost i kreativnost, empatija itd... Lideri u organizacijama radi uspešnosti njihovih organizacija kao i svog prosperiteta moraju da "misle i deluju kao preduzetnici". (Šimundža, 2013, str. 31) Preduzetnički lider aktivno traži mogućnost, prilike, promišljeno reskira uvodeći promene $\mathrm{i}$ poboljšanja. Nužnost preduzetničkog ponašanja lidera mora ići linijom cele organizacije, a ne samo na njenom vrhu, kako bi organizacija preduzetnički bila oblikovana i kao takva se ponašala na tržištu. Lideri u organizaciji moraju biti usmereni na traženje mogućnosti i prilika za poboljšanje uspešnosti svoje organizacije. Zapravo, preduzetnički duh je potrebno osigurati u celoj organizaciji, ali primat se svakako mora dati prvoj liniji rukovođenja. Tako se u stručnoj literaturi i praksi modernih kompanija može naći mišljenje da moderni lideri sve više postaju „preduzetnici u korporacijskoj okolini“. Njihov osnovni zadatak je uvođenje promena, uspešno upravljanje njima i stvaranje sinteze ljudi, resursa, ideja i mogućnosti, odnosno prilika. Preduzetništvo u najširem smislu označava slobodnu inicijativu, uz sankcije koje se izražavaju u vidu dobitka ili gubitka. Ono se odnosi na sve oblike proizvodnje (uključujući tehnologiju i organizaciju), marketing i finansije. U svim akcijama preduzetnik ide na veći ili manji rizik, zbog neizvesne budućnosti. Ali, u tome se ne sastoji proizvodna funkcija preduzetnika. Bitnost njegove funkcije je inovativnost, kreiranje novih kombinacija, fajtera proizvodnje i finansija. Inovativnost povećava produktivnosti i smanjuje troškove. Sa značajnim kvalitetom i kvantitetom radova koji se odnose na preduzetništvo „širi se preduzetnička teorijska džungla" koju prati „empirijska preduzetnička džungla“. Pojam preduzetnika i preduzetništva vezuje se za definiciju po kojoj je to korisna teorijska apstrakcija u koju se mogu svrstati najrazličitiji sadržaji. Preduzetnička organizacija je koncipirana na iskustvu i decentralizaciji, jer svako unapređenje gradi na prethodnom napretku, a svako u preduzeću ima mogućnosti da $\mathrm{u}$ tome učestvuje. Orijentacija na stalne promene, inovacije i razvoj je ukupna odrednica preduzetničke organizacije. Preduzetništvo postaje stil ponašanja izuzetno turbulentne okoline i strategije organizacije u odnosu na tu okolinu u bilo kom području delovanja. To je ne samo sposobnost i stav koji se širi kroz celu kompaniju nego kroz celo društvo i sve društvene delatnosti. Organizacija preduzetnika uočava, otkriva i koristi nove mogućnosti i prilike u okolini, brzo se prilagođava promenama koristeći iste kao spiritus movens svog postojanja i opstanka. Orijentacija na razvoj, stalne promene i 
permanentno stvaranje novog, kao odgovor na turbulentne i neizvesne zahteve okoline, intezivirale su proces preduzetništva, uopšte, stimulisanje preduzetničkog ponašanja na svim nivoima unutar velikih organizacija. (Baroš, 2007) Konsekventno tome, inicirane su bitne promene $u$ odnosu prema ljudima i upravljanju ljudskim resursima, strategijom, kulturom, strukturom i sistemom menadžmenta kao distinktivnim oznakama preduzetničke organizacije. Snaga preduzetništva počiva na ljudima, na njihovoj hrabrosti da se upuste u neizvesnost. Uspešne preduzetničke kompanije svoj procvat i opstanak zasnivaju na snazi ljudske komponente i imaginacije svojih preduzetnika. Ključ uspešnosti su ljudi, njihove kreativnosti sposobnosti, znanje i imagincija kao najvažniji resursi. Razvoj preduzetničke organizacije zasnovan je na znanju, veštini i razvoju ukupnih sposobnosti svih zaposlenih. Snažan podsticaj dobija individualna kreacija i inicijativa, odnosno stvaranje i širenje preduzetničkog duha. Zajedno sa tim razvija se posebna strategija kao osnovna dimenzija organizacije za korespondiranje sa okolinom i unutar sebe. Strategija organizacije predstavlja širok i opšti plan razvijen da se postignu dugoročno organizacijski ciljevi odnosno način na koji kompanija namerava poboljšati svoju poziciju vis-à-vis konkurencije. Inovacije menjaju resurse i daju potencijal za stvaranje novog bogatstva i prosperiteta. Veliki broj analiza mnogih autora bile su usmerene da se identifikuje preduzetnički menadžment. Osobine preduzetnika-lidera su: sposobnost da kontroliše ponašanje i emocije; da motiviše; da bude objektivan; da menja ponašanje drugih u cilju ostvarivanja određene namere; da kreira uloge; da ima samopouzdanje; da je orijentisan na efikasnost; da je zainteresovan za visok kvalitet rada; da sistematično planira i kontroliše; da uvažava značaj poslovnih veza. Pogrešno je tumačiti da preduzetnik-lider prekriva samo vrh piramide rukovođenja. On, naprotiv prekriva sve nivoe menadžmenta. Njegova suština nalazi se ambijentu da svi učesnici u privređivanju traže uslove boljeg privređivanja, bolje efikasnosti $i$ realizacije zadataka preduzeća (neizvesnost $\mathrm{i}$ promene vidi kao prilike i šanse, orijentisan na budućnost i dugoročnu perspektivu, nosilac promena, usmeren na inovacije i njihovu komercijalizaciju, preuzima i toleriše rizik, preferira i bira stručne saradnike, nagrađuje idejeznanje-timski rad kao i orijentacija na rezultate organizacije,,). Preduzetničko liderstvo ima zadatak da u kolektivu spreči duh prosečnosti, orijentišući organizaciju ka ostvarenju maksimalnih efekata. Razume se, ovakav trend se može postići ukoliko je orijentisan ka stalnim promenama, strategiji, inovaciji i prihvatanju dimanike iz okruženja. Jedno od njegovih osnovnih obeležja jeste da je nesigurnost i rizik bitan uslov u kome se ovaj proces odvija. Razume se, ovo je samo jedna od mogućih „lista“ u koju su unete razlike lidera preduzetničkog i nepreduzetničkog tipa i orijentacije. (Bebera, Leković, \& Vasiljev, 2008, str. 32) Budući da postoji visoka interakcija između naznačenih osobina, to su moguća različita ispoljavanja u konkretnim situacijama. Preduzetništvo se ne može posmatrati kao nužnost postojanja svih, odnosno odsustvo svih navedenih osobina (po principu sve ili ništa), s obzirom da konkretna situacija i društvena stvarnost određuje optimalne oblike preduzetničkog ponašanja. Postoje dva pravca koja su bazirana na liderstvu u preduzetništvu. Prvi pravac je skoncentrisan unutar škole "velike ličnosti" i u osnovi se zasniva na liderskim karakteristikama koje doprinose uspehu firme (adaptibilnost novonastalim uslovima okruženja, kooperativnost, energičnost, spremnost za preduzimanje odgovornosti). Drugi pravac se odnosi na izučavanje sposobnosti preduzetnika - lidera da uradi određeni posao, kao i na njegov odnos sa ljudima koji rade na određenom poslu. Često se ističe da preduzetnici svoj liderski stil treba da prilagođavaju situaciji u kojoj se nalaze. Preduzetničko liderstvo podrazumeva ne samo značaj ličnih osobina i načina ophođenja i komuniciranja sa saradnicima, već i sposobnost da se saradnici podstaknu na veće napore i ostvarenja, kroz proces motivacije i respektovanja njihovih rezultata. Često se pravi distinkcija između liderstva i sprovođenja kontrole nad ljudima. Preduzetnik je uključen u kompleksnu društvenu "mrežu" koja može da ometa ili pospešuje razvoj biznisa. "Mreža" može da obezbedi ideje, pristup određenim resursima, izbor ljudi koji na najbolji način mogu da realizuju određenu ideju u praksi. Najefikasniji i najuspešniji su oni lideri koji kreiraju ideje i vizije, razvijaju in i konkretno realizuju. Za razliku od liderstva u čijoj se suštini nalazi uticaj 
kao osnovni faktor uspeha, preduzetništvo se zasniva na rizicima, pošto je preduzetnik obično i vlasnik sredstava za proizvodnju. Preduzetniklider promišljeno reskira i aktivno traži mogućnost za uvođenje novih promena i poboljšanja ličnog poslovanja. Suština preduzetničkog liderstva orijentisana je na uspešnost privređivanja. (Bobara, 2012, str. 89) Za preduzetničko liderstvo dobro obavljen posao je samo potreban uslov, pri čemu je od naročitog značaja da se obavlja dobar posao. Značajan faktor uspešnosti privređivanja je u očuvanju konkurentske prednosti za realizaciju ciljeva preduzeća. Svaka konkurentska prednost podrazumeva uvođenje novih prizvoda, oblika i metoda rada kao i život sa rizikom i neizvešnošću. Različitost ne sme biti sama sebi cilj, već mora biti tretirana sa aspekta kupca. Kupac je jedini akter koji uočava i nagraĐuje različitost, hrabrost, nove ideje, promene i inovacije. Međutim, konkurentska prednost preduzetnika ne sme se isključivo vezati za promene $i$ inovacije $u$ sferi proizvodnje $i$ proizvoda. Takav okvir deluje prilično monotono $\mathrm{i}$ bez dovoljne invencije. Znatno širi prostor za ostvarivanje konkurentske prednosti sadržan je u sferi upravljanja, s obzirom da su potencijalni efekti jednaki ili veći od onih koji se nalaze, odnosno nude tehničke inovacije. Budućnost preduzeća uslovljena je delovanjem razvijene mreže faktora koji deluju međuzavisno u cilju izmene vođenja preduzeća da bi se iskoristile sve prednosti, a štetni uticaji sveli na najmanju meru. $\mathrm{U}$ poslednje vreme je aktuelna "liderska" škola preduzetništva. Ova škola predstavlja netehnički pristup koji znači da preduzetnici moraju da poseduju određeno umeće i veštine u obraćanju i komuniciranju sa okruženjem. Uspešni preduzetnik mora da bude i efikasan "menadžer ljudskim resursima”, tj. efikasni lider koji igra glavnu ulogu u motivisanju i usmeravanju ljudi, a koji je sposoban da definiše viziju onoga što je moguće da privuče ljude oko te ideje $i$ da in organizuje tako da oni na najbolji način tu ideju transformišu i realizuju u praksi.

\section{PREDUZETNIŠTVO KAO EFEKTIVNO LIDERSTVO}

Budući da se uspešan lider ne rađa, nego stvara neophodno je da postoje određene pretpostavke uspešnog liderstva. A svako uspešno liderstvo mora imati atribut preduzetničkog. Imajući u vidu brojne elemente $u$ datim teorijama o fenomenu liderstva, moguće je iskazati model efektivnog liderstva, odnosno uočiti one faktore koji određuju njegovu efektivnost. $U$ te faktore treba ubrojiti sledeće: preciznost percepcije, karakterisitke lidera, karakterisitke sledbeniika, očekivanja i stil pretpostavljenih, razumljivost zadataka i očekivanja drugih idera. (Babović, 2012, str. 41)

Poznavanje i spremnost na komuniciranje su pretpostavke koje su od bitne važnosti za uspešnost liderstva. Kako je liderstvo proces koji je imanentan različitim organizacionim nivoima, to je normalno da će oni imati svoje pretpostavljene. Pored navedenih, postoji i niz drugih faktora čiji uticaj može biti manje - više značajan za uspeh lidera. Jedan od tih faktora ogleda se u životnom ciklusu preduzeća koji uključuje nekoliko faza: fazu izgradnje, rasta, zrelosti, opadanja i nestajanja. Treba nedvosmisleno naglasiti da je penetracija moći direktno proporcionalna rastu i razvoju preduzeća i da sa sa njim nalazi u direktnoj korelaciji. Naime, sa razvojem i rastom preduzeća struktura moći postaje kompleksnija, difuznija, manje funkcionalna, ali i stabilnija. Jako vođstvo ispoljava se na početku razvoja organizacije, da bi se u kasnijoj fazi usled disperzije i veće otvorenosti ka spoljnjem svetu pojavila instrumentalna i misionarska konfiguracija moći. U fazi zrelosti struktura moći se ponovo kostituiše, da bi u poslednjoj fazi postala difuzna rađajući konfliktne situacije. Liderstvo predstavlja svojevrsno ponašanje ličnosti koja afirmativno deluje na percepciju, osećaje i ponašanje drugih ljudi. Stoga, liderstvo insistira na socijalnim veštinama u menadžmentu kako bi se istim ostvarili ciljevi organizacije. Lideri-preduzetnici poseduju posebne, dodatne uloge i funkcije usmerene ka prosperitetu preduzeća. Oni (lideri-preduzetnici) objedninjuju sposobnost mobilizatora i aktivatora grupe, postaju njihovi ambasadori, model i primer za ponašanje drugih. Od svega ovoga može se postaviti pitanje šta, zapravo, lideri-preduzetnici u organizaciji obavljaju, ako prethodno navedene kvalitete poseduju, čime se konkretno bave $\mathrm{i}$ kakve su njihove aktivnosti? Mada među naučnim radnicima ima brojnih nabrajanja o neposrednom radu lidera-preduzetnika u organizaciji, mi ćemo se opredeliti za one aktivnosti koje smatramo 
relevantnim sadašnjem trenutku, verujući da time nisu iscrpljene sve radnje koje bi bile od koristi za organizaciju. Na osnovu većeg broja klasifikacija moguće je navesti sledeće aktivnosti:

- koordiniranje grupnih aktivnosti organizacije,

- aktiviranje i posredovanje u integriranim konfliktima,

- osvetljavanje ciljeva, osiguranje vizije i inspirisanje,

- objašnjenja i sugeriranje rešenja,

- iniciranje i ubrzanje aktivnosti,

- reprezentacija organizacije prema spoljnjem svetu

- pružanje sigurnosti i optimizma u problemskim situacijama,

- nagrađivanje,

- integrisanje organizacije,

- obnavljanje i razvoj organizacije. (Karavidić, 2018, str. 49)

$\mathrm{U}$ korespondiranju i komuniciranju sa saradnicima i ljudima van sopstvene organizacije lider-preduzetnik mora veliku pažnju da posveti osećaju šta i kako govori i šta i kako radi, jer daje primer drugim. Široko priznanje znači više odgovornosti: pažljivije se posmatra, pažljivije sluša i oponaša. On predstavlja primer za ugled.

Dobri lideri-preduzetnici govore i slušaju dobro. Njihova prednost se ogleda u osećaju trenutka kada da vode, a kada da slede. Uspešni lideripreduzetnici uza sebe imaju veoma jak tim, a i u samom timu može biti vođa. Dobri lideripreduzetnici poseduju sposobnost vizije današnjice i sutrašnjice, jer razlikuju bitno od nebitnog. Njihov rad se zasniva sa drugima $i$ preko drugih. Pored navedenih osobina $u$ prethodnom delu da bi neko bio uspešan lider preduzetnik mora da poseduje još i sledeće karakteristike:

- sposobnosti: inteligencija, snalažljivost, originalnost, potreba potvrđivanja uspeha,

- dostignuća: vezano za dostignuća u znanju, obrazovanju,

- odgovornost koja je povezana sa osobinama ličnosti kao što su zavisnost, agresivnost, samopotvrđivanje s komunikativnošću, koopertivnost i inicijativnost,

- participacija povezana s komunikativnošću, kooperativnošću, prilagođenošću i slično.

- Bilo bi dobro da lider-preduzetnik ima i neke od sledećih karakteristika:
- samosvest-kao izraz o sopstvenoj ličnosti, mogućnostima i načinu uticaja,

- samopouzdanje-sposobnost vođenja i rešavanja problema ali i preuzimanja rizika,

- sposobnost komuniciranja izraženu kroz prenošenje ličnih ideja i efikasno kontaktiranje s drugima.

Pored iznetih karakteristika dobrog liderapreduzetnika moguće je uneti i niz drugih značajnih osobenosti koje na određen način snažnije deskriptuju ličnost lidera. Tu pre svega imamo u vidu njegovu spremnost da vodi. Ako lidera-preduzetnika privlači izazov, stvaranje nečega što je do tada izgledalo nemoguće, tada je on iskusio „poziv“ lidera. Ukoliko je pored ovoga spreman da učestvuje u poslovnim iskušenjima i riziku, tada on poseduje „stav lidera“. Ako je pri svemu ovome to radio redovno, takva ličnost postaje lider. Njegov radni moral mora uticati na druge. Taj moral se ne odnosi samo na marljivost, već i odnos prema preduzeću, potrošačima, radnicima, ali i svim akcijama koje on mora učiniti da bi njegova korelacija pobedila na tržištu. On postaje ličnost koja radi u skladu sa onim što govori. Doslednost i entuzijazam u ostvarenju cilja i zadataka organizacije se nameću kao imperativ uspešnosti kompanije. Svoju aktivnost lider-preduzetnik zasniva na mogućnosti da delegira ukazujući time poverenje saradnicima. Dobar lider-preduzetnik:

- govori istinu,

- priznaje greške i ispravlja greške drugih,

- priznaje svoje neznanje kada nešto ne zna,

- bira dobre saradnike,

- drži dato obećanje,

- podržava inovacije, nagrađuje uspeh i podržava svoje radnike, čak i kada greše,

- interesantan je, zato što je zainteresovan,

- veruju mu, zato što i sam veruje,

- ličnim primerom otklanja sumnju,

- uvek ima više od jedne dobre ideje.

Ono što lidera razlikuje od menadžera to je vizija odnosno vizionarsko ponašanje. Lider sa vizijom je i okosnica organizacije koja uči (OKU). Vizija mora biti prihvaćena od svih zaposlenih u organizaciji. Od lidera se očekuje da pridobija i zadržava ljude time što globalno mora da ga krasi konstantnost, kongruentnost, pouzdanost i integritet. Lider je, dakle savremeni preduzetnik koji omogućava da preduzeće preživi preko 
upravljanja promenama, a menadžer je maksimizator efekata promena. I jedan i drugi su izloženi efektu "makaza vremena", što znači da se sve veći broj sve složenijih problema treba da reše za sve kraće vreme. Menadžer traži aktivnost sa drugim ljudima i poseduje niži nivo emocionalne veze sa poslom dok je lider zaokupljen vizijom i uspehom, pa ga jače emocije vezuju za posao. Oni različito tumače istu pojavu. Lider-preduzetnik kao strateg u stvaranju vizije preduzeća oslanja se na talenat imaginacije koja mu omogućava da pokrene zaposlene $u$ stvaranju većeg "rada" nego što bi učinili pod normalnim okolnostima. Zato valja imati $u$ vidu njegovu vizionarsku sposobnost da od prosecnog ili lošeg preduzeća napravi dobre, odnosno natprosečne poslovne rezultate. Liderpreduzetnik ne sme biti usamljen. $\mathrm{Na}$ vrhu piramide preduzeća neophodno je da menadžeri imaju istu kulturu. Posedovanje iste kulture osnovni je predznak da se strategijske vizije prihvate i pronađu pravi za realizaciju ciljeva preduzeća. Danas može da vodi ljude samo "transformacioni" i "reprezentativni" lider koji inspiriše ljude, koji se identifikuju sa jednim zajedničkim ciljem (vizijom) i koji u rešavanju tog cilja ulažu svoju kreativnu energiju. (Karić, 1992, str. 99) Osnovna osobina dobrog liderapreduzetnika je njegova umešnost da projektuje promene bez obzira u kojoj se fazi životnog ciklusa nalazila organizacija. Kao kreator i stvaralac promena on je duhom ispred ostalih. On poseduje moć okupljanja drugih oko njegove ideje i realizacije iste. Zbog ovoga se smatra da na početku svake životne faze organizacije stoji vizija budućnosti, nešto više što bi mogli nazvati jednostavno plan ili program. Vizija predstavlja odgovarajuću, usmeravajuću silu koja organizuje i kanališe energiju pojedinca ka realizaciji budućeg cilja. Definisanje vizionarske sposobnosti je neophodno za pronalaženje unosnih poslova i tržišta od strane preduzeća, čime se stvara konkurentska prednost na tržištu.

\section{ULOGA PREDUZETNIŠTVA U EKONOMSKOM RAZVOJU}

Postoje argumenti u literaturi koji ukazuji da preduzetništvo nema direktnu vezu sa ekonomskim rastom. To je zato što se širi pogled na ekonomski razvoj ne izjednačava sa ekonomskim rastom i produktivnošću. Takođe, sami teoretičari preduzetništva istakli su da koordinacija resursa, kreiranje novih poslova i inovacije ne moraju nužno da generišu rast.

Ekonomisti koji se bave razvojem prepoznaju značaj otvaranja novih radnih mesta, preuzimanje rizika, učenje, inovacije, eksperimentisanje i konkurenciju. $U$ tom kontekstu, oni ne spore ogroman doprinos preduzetništva i preduzetnika. Postoji saglasnost da postoji veliki broj preduzetnika u zemljama u razvoju koji su doprineli ekonomskom razvoju u neformalnom sektoru. Neki čak i smatraju takve neformalne preduzetnike kao neophodne za rast u zemljama u razvoju. Ovi preduzetnici doprinose smanjenju siromaštva u zemljama u razvoju.

Dok takvi preduzetnici ne predstavljaju prepreku ekonomskom razvoju, generalno ne smatraju se pokretačima ekonomskog rasta. Umesto toga, mnogi ekonomisti koji se bave razvojem smatraju da takvi neformalni preduzetnici su simptomi drugih ograničenja u privredi. S toga, stoji tvrdnja da relevantno odsustvo preduzetnika $u$ ekonomijama u razvoju nije ono što je najvažnije za razvoj, posebno ne u najsiromašnijim zamljama. Postoje i druga više obavezujuća ograničenja.

Pored ovih argumenata postoje, i mnogi drugi naučnici, posebno oni u oblasti ekonomije koji tvrde da postoji pozitivna korelacija između preduzetništva i ekonomskog razvoja. Ovi naučnici tvrde da je preduzetništvo ključna determinanta rasta i razvoja posebno u zemljama u razvoju. Preduzetništvo igra veoma važnu ulogu, kako u razvijenim zemljama, tako i u zemljama u razvoju. Ekonomska istorija najrazvijenijih zemalja sveta kao što su Amerika i Japan, govori u prilog činjenici da je preduzetništvo odigralo ključnu ulogu u njihovom razvoju. (Petković, 2009, str. 87)

Poslednjih godina i kreatori ekonomskih politika i istraživači preduzetništva sve veću pažnju posvećuju malim preduzećima. Postalo je široko priznato da više start-up i malih preduzeća igraju važnu ulogu u ekonomskom rastu. Postoji shvatanje da povećanje preduzetništva i kvantitativno i kvalitativno u zemljama u razvoju je preduslov za generisanje ekonomskog razvoja. Preduzetništvo je kritično značajna dimenzija za 
predviđanje i objašnjenje ekonomskih performansi zemalja posebno onih u razvoju.

Jedna od ključnih oblasti gde preduzetništvo doprinosi ekonomskom razvoju je zapošljavanje. Generalno je priznato da mala preduzeća igraju važnu ulogu u ekonomskom rastu kroz zapošljavanje. Jedna od odrednica ekonomskog razvoja je stopa zaposlenosti. Većina zemalja u razvoju imaju visoku stopu nezaposlenosti. Preduzetništvo doprinosi razvoju kroz kreiranje radnih mesta ili samozapošljavanju. Tako, preduzetništvo i /ili mala preduzeća su preduslov za promovisanje zapošljavanja, borbe protiv siromaštva i stimulisanje održivog ekonomskog rasta. Preduzetništvo je katalizator za otvaranje novih radnih mesta, rast proizvodnje, tehnološki napredak, zamena uvoza, poboljšanje kvaliteta proizvodnje, promocija izvoza i snabdevanje proizvoda po pristupačnim cenama za potrošače. Postoji potreba, dakle, za razvojem preduzetničke kulture u zemljama u razvoju ne samo kao sredstvo za otvaranje novih radnih mesta, već i kao način infuzije preduzetničkog razmišljanja i ponašanja društva koji nije potpuno posvećen tome. Na taj način mala i srednja preduzeća igraju ključnu ulogu ne samo na nacionalnom nivou, već su i važan motor za razvoj lokalnih ekonomija i zajednica.

Preduzetništvo je od ključnog značaja u obezbeđivanju efektivnog i efikasnog ekonomskog sistema. Wickham (2004) naglašava da preduzetnici imaju važan pozitivan efekat na ekonomije širom sveta. Oni imaju važnu ulogu u održavanju i razvijanju ekonomskog poretka. Preduzetništvo ima pozitivan uticaj na makroekonomski rast, uvođenje inovacija i poslovnih kreacija. Tri osnovna ekonomska faktora: sirovine, radna snaga i kapital su ekonomski faktori koje preduzetnik kombinuje i koji stvaraju vrednost koja zadovoljava ljudske potrebe. Acs i Storey (2004) takođe, su pronašli vezu između osnivanja novih firmi i ekonomskog razvoja. Autori kažu da se preduzetništvo smatra faktorom proizvodnje, a proizvodnja je poboljšana ne samo povećanjem količine rada, kapitala $i$ znanja, već i po tome kako preduzetništvo poboljšava raspodelu ovih faktora u ekonomiji.

Doprinos preduzetništva rastu i razvoju, međutim, nije svuda isti i razlikuje se od zemlje do zemlje. Ova razlika postoji čak i na regionalnom i lokalnom nivou. Ova razlika potiče od različitih nivoa ekonomske razvijenosti između zemalja. Vohra (2006) potkrepljuje ovu činjenicu objašnjavajući da uloga preduzetništva u ekonomskom razvoju varira od ekonomije do ekonomije u zavisnosti od materijalnih sredstava, industrijske klime i sigurnog političkog sistema u preduzetničkoj funkciji u ekonomiji. Kako je preduzetništvo direktno povezano sa ekonomskim razvojem, postoji hitna potreba za izgradnjom preduzetničkih kapaciteta za restrukturiranje aktivnosti preduzetnika u cilju boljitka celokupnog društva. Tako pišući o „ulozi preduzetništva na ekonomski razvoj" Hisrich, Peters i Shepherd (2008) otkrivaju da se uloga preduzetništva u ekonomskom razvoju podrazumeva više nego samo povećanje društvenog dohotka, produktivnosti i prihoda; uključuje iniciranje i konstituisanje promene $u$ strukturi privrede i društva. Promena, tvrde oni, prati rast i povećanje prihoda koji omogućava više bogatstva. (Petrović, Cvijanović, \& Vukotić, 2014, str. 93)

\section{ZAKLJUČAK}

Fenomen preduzetništva nalazi se u uzročnoposledičnoj vezi sa fenomenom promene. Kao što promene nastaju usled nekih preduzetničkih aktivnosti, tako isto preduzetničke inicjative rezultuju kao odgovor na neke promene. Klasična definicija preduzetništva je da je to skup ljudskih aktivnosti na kombinovanju resursa radi ostvarivanja određenog poslovnog cilja. Preduzetništvo se oslanja na pojedince koji posebnim postupkom oblikuju stvarnost u težnji da na najbolji način iskoriste svoje i/ili tuđe znanje i iskustvo, sopstvena ili pozajmljena sredstva, raspoloživu opremu, objekte i ostalo što je neophodno da bi se krenulo u određene poslovne poduhvate.

Fenomen promena javlja se u uzročnoposledičnoj vezi sa glavnim megatrendovima koji oblikuju današnji svet. Među tim megatrendovima (koji se takođe nalaze u međusobnoj uzročno posledičnoj vezi) posebno se izdvajaju:

- Globalizacija

- Tehnološki razvoj - informatika, kompjuterizacija i robotizacija

- Strukturne promene - kreativne industrije

- Organizacione promene 
- Institucionalne promene

- Demografske promene

- Sociološke promene i

- Psihološke promene

Turbulentno okruženje postavlja nove, sve brojnije i sve teže izazove pred sve subjekte razvoja. Razvoj, pa čak i sam opstanak subjekata razvoja, zavisi od odgovora koji se pružaju na te složene izazove. Odgovori na promene $u$ okruženju zahtevaju promene kod samih subjekata razvoja. Oduvek je preduzetništvo predstavljalo adekvatan odgovor na izazove okruženja. Sada, iako su izazovi okruženja teži i složeniji nego ranije, gotovo sve pojedinačne sile sadržane u prikazanim megatrendovima, pa i njihove rezultante, deluju podsticajnije nego ikada na razvoj fenomena preduzetništva. Kako preduzetničke prilike proizlaze iz tržišnih promena, savremeno, brzo promenljivo i nesigurno poslovno okruženje predstavlja teoretski potencijalnu oblast za preduzetničke aktivnosti.

\section{CITIRANA DELA}

Acs, Z., \& Storey, D. (2004). Introduction: Entrepreneurship and Economic Development. Regional Studies, 38(8), 871-877. doi:10.1080/0034340042000280901

Babović, M. (2012). Prepreke i potencijali preduzetništva žena u Srbiji. Beograd: Program Ujedinjenih nacija.

Baroš, Ž. (2007). Preduzetništvo i preduzetnički menadžment. Banja Luka: Panevropski univerzitet Apeiron.

Bebera, D., Leković, B., \& Vasiljev, S. (2008). Preduzetništvo u Srbiji. Subotica: Ekonomski fakultet.

Bobara, D. (2012). Preduzetništvo. Doboj: Visoka poslovno-tehnička škola.

Karić, B. (1992). Mala privreda i preduzetništvo. Beograd: Ekonomika.

Karavidić, S. (2018). Preduzetništvo: savremene tendencije razvoja. Beograd: Visoka škola za poslovnu ekonomiju i preduzetništvo.

OECD. (1998). OECD Employment Outlook 1998 - Towards an employment-centred social policy. Preuzeto sa OECD.org: https://www.oecd.org/els/emp/oecdemploymentoutlook1998towardsanemployment-centredsocialpolicy.htm

Praag, C. M., \& Versloot, P. H. (2007). What is the value of entrepreneurship? A review of recent research. Small Business Economics(29), 351-382. doi:10.1007/s11187-007-9074-x

Petković, V. (2009). Preduzetništvo. Beograd: Visoka škola za poslovnu ekonomiju i preduzetništvo.

Petrović, Ž., Cvijanović, D., \& Vukotić, S. (2014). Preuzetnička orijentacija malih preduzeća u Srbiji. Beograd: Institut za ekonomiku poljoprivrede.

Radovanović, T. (2006). Razvojni problemi samostalnog preduzetništva u Srbiji i njihovo rešavanje. Beograd: Unija poslodavaca Srbije.

Schumacher, E. F. (1973). Small is Beautiful - Economics as If People Mattered. London: Blond \& Briggs.

Šimundža, A. (2013). Preduzetništvo: praktičan vodič. Beograd: Ministarstvo poljoprivrede Republike Srbije.

Wickham, P. A. (2004). Strategic Entrepreneurship. Financial Times Prentice Hall.

Received for publication: $\quad 24.09 .2020$.

Revision received: $\quad$ 23.03.2021.

Accepted for publication: $\quad$ 05.04.2021. 
Kako citirati ovaj rad? / How to cite this article?

Style - APA Sixth Edition:

Miličković, M., Alshafie, B. Z., \& Jevremović, M. (2021, 04 15). Uticaj razvoja preduzetništva i liderstva na ekonomski razvoj. (Z. Čekerevac, Ur.) FBIM Transactions, 9(1), 70-80. doi:10.12709/fbim.09.09.01.07

Style - Chicago Sixteenth Edition:

Miličković, Milosav, Bilal Zahrah Miftah Alshafie, i Miroslav Jevremović. 2021. „Uticaj razvoja preduzetništva i liderstva na ekonomski razvoj. "Urednik Zoran Čekerevac. FBIM Transactions (MESTE) 9 (1): 70-80. doi:10.12709/fbim.09.09.01.07.

Style - GOST Name Sort:

Miličković Milosav, Alshafie Bilal Zahrah Miftah i Jevremović Miroslav Uticaj razvoja preduzetništva i liderstva na ekonomski razvoj [Časopis] // FBIM Transactions / ur. Čekerevac Zoran. Beograd : MESTE, 1504 2021. - 1 : T. 9. - str. 70-80.

Style - Harvard Anglia:

Miličković, M., Alshafie, B. Z. M. \& Jevremović, M., 2021. Uticaj razvoja preduzetništva i liderstva na ekonomski razvoj. FBIM Transactions, 15 04, 9(1), pp. 70-80.

Style - ISO 690 Numerical Reference:

Uticaj razvoja preduzetništva i liderstva na ekonomski razvoj. Miličković, Milosav, Alshafie, Bilal Zahrah Miftah i Jevremović, Miroslav. [ur.] Zoran Čekerevac. 1, Beograd : MESTE, 1504 2021, FBIM Transactions, T. 9, str. 70-80. 